
\title{
3 Research Square \\ Chronic cough in postmenopausal women and its associations to climacteric symptoms
}

\section{Volker Ziller}

University of Marburg: Philipps-Universitat Marburg

Thea Sophie Oppermann ( $\nabla$ thea-oppermann@gmx.net )

University of Marburg: Philipps-Universitat Marburg https://orcid.org/0000-0001-8907-7327

\section{Werner Cassel}

Universitatsklinikum Giessen und Marburg - Standort Marburg

\section{Olaf Hildebrandt}

Universitätsklinikum Gießen und Marburg - Standort Marburg: Universitatsklinikum Giessen und

Marburg - Standort Marburg

\section{Rolf Kroidl}

Universitätsklinikum Gießen und Marburg - Standort Marburg: Universitatsklinikum Giessen und Marburg - Standort Marburg

\section{Ulrich Koehler}

Universitätsklinikum Gießen und Marburg - Standort Marburg: Universitatsklinikum Giessen und Marburg - Standort Marburg

\section{Research Article}

Keywords: chronic cough, menopause, Menopause Rating Scale (MRS), Leicester Cough Questionnaire (LCQ)

Posted Date: April 18th, 2022

DOI: https://doi.org/10.21203/rs.3.rs-1034215/v2

License: (c) (i) This work is licensed under a Creative Commons Attribution 4.0 International License. Read Full License 


\section{Abstract \\ Background}

Postmenopausal women often have chronic cough, which is likely caused by hormonal changes affecting lung function and the mucous membrane of the airways, causing hypersensitivity of the cough reflex. Therefore, postmenopausal hormonal changes could play a key role in the association between increased cough and menopause. The aim of this study is to evaluate the relation of chronic cough and postmenopausal symptoms.

\section{Methods}

We performed a questionnaire-based cohort study in generally healthy postmenopausal women (age 4565 years). Women with cough of known origin were excluded. Comorbidities, medication and baseline data were collected. The Menopause Rating Scale II (MRS II) was combined with the Leicester Cough Questionnaire (LCQ). Groups were divided in chronic cough versus non-coughing participants, chronic cough was defined as 'symptoms for over 8 week'. We performed correlations and logistic regression for predicting cough based on postmenopausal symptoms.

\section{Results}

66 of 200 women (33\%) reported mild to heavier symptoms of chronic cough for over 8 weeks. No significant differences in baseline data (age, BMI, onset of menopause, years since menopause, concomitant diseases, and medication) were found between coughing and non-coughing women. The MRS II showed higher menopausal symptoms in patients with cough, with significant differences in 2 of the 3 MRS-domains (urogenital $(p<0.001)$ and somato-vegetative $(p<0.001)$ ). Climacteric symptoms strongly correlated with parameters of cough $(p<0.001)$. On the basis of the MRS total score $(p<0.001)$ and the somato-vegetative and urogenital domains $(p<0,05)$, the prediction for respiratory complaints could be shown.

\section{Discussion}

Chronic cough was significantly associated with menopausal symptoms. Therefore chronic cough as a possible climacteric symptom and its underlying mechanisms should be further explored.

\section{Purpose}

Chronic cough in adults is defined by its persistence for at least 8 weeks [1-4]. Chronic cough is associated with a significant impairment of physical performance and quality of life [5-11]. In a relevant number of patients, etiology of chronic cough remains unclear despite extensive diagnostics. The cough 
receptor's hypersensitivity seems to be an underlying factor. Middle-aged women who complain of chronic cough are suspected to have a causal relationship between coughing irritation and postmenopausal changes [12-16].

Menopause is a complex phenomenon. The cessation of the ovarian activity and the subsequent lack of sex steroids, especially estrogen and progesterone, results in substantial changes in the female body that are generally summarized as "climacteric syndrome." Typically, among other symptoms, this includes hot flashes, sweats and vaginal atrophy, as well as muscle and joint complaints [17-20]. The changes in skin, connective tissue and mucous membranes from the lack of estrogen could also manifest in the respiratory tract. As estrogen deficiency leads to atrophy of vaginal epithelia, reduction or modification in mucus, ciliae or changes in sensitivity in respiratory tissue could cause a reduction in lung function and lead to chronic cough [21-27]. If postmenopausal estrogen deficiency plays a part in the development of cough the extend of climacteric symptoms should be correlated to symptoms of cough.

It was therefore the aim of this study to investigate the relationship between postmenopausal symptoms and chronic cough.

\section{Methods}

We performed a questionnaire-based cohort study in postmenopausal women recruited within the outpatient consultation at the University Hospital Marburg, Germany. The women visited the gynecological department for numerous medical reasons, but the majority took part in routine checkups or menopausal counseling including bone densitometry (performed by the department of gynecological endocrinology in our hospital). Participants between the ages of 45 and 65 were offered participation, although the last menstruation had to be at least one year ago.

We excluded women with irregular bleeding, smokers, history of any recent sex steroid treatment or any differential diagnosis that might be connected to chronic cough (e.g. cancer, chronic bronchitis, gastroesophageal reflux, chronic heart failure, therapy with ace-inhibitors).

\section{Study procedures}

After written informed consent, specified inclusion and exclusion criteria, as well as the differential diagnoses for chronic cough, were queried and documented. When all criteria for participation were met, the severity of menopausal symptoms and the severity of cough were measured using the Menopause Rating Scale II and the Leicester Cough Questionnaire LCQ [28, 29].

\section{Menopause Rating Scale II (MRS II)}

The MRS II is a simple, flexible, and quickly implementable tool for evaluating postmenopausal symptoms [29,30]. The 11 symptoms are given on a 5 -point Likert scale $(0=$ no complaints to $4=$ very severe complaints) [31]. The total score can range from 0 (asymptomatic) to 44 (highest level of 
complaints). A low scale value correlates with a higher quality of life. ${ }^{31}$ Within the MRS II, 3 subgroups can be distinguished. The "somato-vegetative" subgroup suffers increasingly from sleep disorders, heart problems, hot flashes and joint/muscle problems (items 1, 2, 3, and 11 with $0-16$ possible points). The "urogenital" type focuses on complaints of the urinary tract, vagina and sexuality (items 8,9 , and 10 with 0-12 possible points). The "mental" subgroup include exhaustion, irritability, anxiety and mood (items 4 , 5,6 , and 7 with $0-16$ possible points) [30]. To calculate the total score for the 3 subscales, the degrees of severity of the associated items are added. To calculate the total number of points, subscale values are combined.

\section{Leicester Cough Questionnaire (LCQ)}

The LCQ consists of 19 items that cover a physical (8 items), mental (7 items), and social (4 items) domains. The physical condition of the patient is inquired through items $1,2,3,9,10,11,14$, and 15 and refers to symptoms that can be associated with cough, including abdominal/chest pain, the production of sputum, fatigue, sleep disorders, hoarseness and changed performance. In addition, certain situations that trigger the cough are recorded. Items 4, 5, 6, 12, 13, 16, and 17 deal with mental aspects: the ability to control the cough reflex and the emotions associated with the symptoms (fears, embarrassment, discouragement, frustration, and worry) play a role in the question selection. Social effects are covered by questions $7,8,18$, and 19 . In this case, the influence of cough symptoms on everyday situations, relationships with family members and on enjoyment of life is asked [28].

The 3 domains are evenly distributed across the entire questionnaire. A maximum total of 133 points can be achieved ( $19 \times 7$ points).

\section{Definition of chronic cough}

Chronic cough is defined as a symptom that persists for at least eight weeks [3,32,33]. The subjects had to give a time indication of the duration of their cough, if it was present.

If this duration was reported for over 8 weeks or longer, we classified them as coughing subjects. There was no minimum level of symptoms, because minor complaints in the context of coughing should also be recorded.

\section{Statistics}

To distinguish a correlation of $r \geq 0.2$ with sufficient test strength (0.8) from $r=0$, an inclusion of $n=200$ patients was planned. The statistical evaluation was carried out with IBM SPSS Statistics Version 22 (IBM GmbH). Due to the high number of cases of $n=200$, parametric test methods were used for descriptive and inferential statistical analyzes. All variables were checked for normal distribution, skewness, and kurtosis. If there was a significant deviation from a normal distribution with very high skew values $(>2)$, then after visually inspecting the distribution, these parameters were either reverted to non-parametric evaluation methods or the variables were transformed, thus making an approximate 
normal distribution for the transformed variables. After defining two cohorts (cough versus non-cough) groups were analyzed by comparisons of means. Correlation analysis and logistic regression were applied to the whole cohort.

\section{Ethics}

The study was conducted in accordance to the guidelines and with approval of the local ethics committee of the Philipps-University of Marburg.

\section{Results}

There were 205 subjects interviewed and included after positive prescreening between July 6th, 2017 and October 18th, 2019. Five test subjects had to be excluded due to differential diagnoses afterwards. Finally, 200 women were included in the analysis.

Of the 200, 66 (33\%) patients had mild to severe symptoms of chronic cough over the last eight weeks. They were compared to the $134(67 \%)$ that had none. There was no statistical difference between the two groups concerning their baseline datap (Table 1).

Table 1

Baseline characteristics

\begin{tabular}{|c|c|c|c|c|c|c|}
\hline \multirow[t]{2}{*}{$n=200$} & \multicolumn{2}{|c|}{ with cough $(n=66)$} & \multicolumn{2}{|c|}{ without cough $(n=134)$} & \multirow[b]{2}{*}{$\begin{array}{l}\text { t-test, } \\
\text { p- } \\
\text { value }\end{array}$} & \multirow[b]{2}{*}{$95 \% \mathrm{Cl}$} \\
\hline & $\begin{array}{l}\text { mean } \\
\text { values }\end{array}$ & $\begin{array}{l}\text { standard } \\
\text { deviation }\end{array}$ & $\begin{array}{l}\text { mean } \\
\text { values }\end{array}$ & $\begin{array}{l}\text { standard } \\
\text { deviation }\end{array}$ & & \\
\hline age (years) & 57.18 & 3.56 & 57.17 & 3.91 & 0.99 & $\begin{array}{l}-1.12 \\
1.14\end{array}$ \\
\hline weight (kg) & 70.38 & 13.83 & 67.82 & 12.23 & 0.19 & $\begin{array}{l}-1.08 \\
1.10\end{array}$ \\
\hline height (cm) & 165.5 & 6.10 & 165.74 & 6.19 & 0.80 & $\begin{array}{l}-2.07 \\
1.59\end{array}$ \\
\hline BMI $\left(\mathrm{kg} / \mathrm{m}^{2}\right)$ & 25.63 & 4.44 & 24.65 & 4.03 & 0.12 & $\begin{array}{l}-0.26 \\
2.21\end{array}$ \\
\hline $\begin{array}{l}\text { years since } \\
\text { menopause }\end{array}$ & 8.05 & 5.60 & 8.15 & 6.27 & 0.91 & $\begin{array}{l}-1.90 \\
1.70\end{array}$ \\
\hline $\begin{array}{l}\text { number of } \\
\text { diseases }\end{array}$ & 1.23 & 0.97 & 1.01 & 1.00 & 0.16 & $\begin{array}{l}-0.08 \\
0.51\end{array}$ \\
\hline $\begin{array}{l}\text { number of } \\
\text { medications }\end{array}$ & 1.10 & 1.45 & 0.79 & 0.99 & 0.09 & $\begin{array}{l}-0.05 \\
0.65\end{array}$ \\
\hline
\end{tabular}


The mean age of the patients in both groups was 57.2 years. They did not significantly differ in terms of weight, height, time since menopause, number of previous illnesses and co-medication. The frequencies of the comorbidities hypothyroidism, osteoporosis, osteopenia and having a hysterectomy did not significantly differ according to the Fisher`s exact test $(p>0.05)$.

The age at the beginning of cough was estimated at 52.6 years on average. The coughing prevailed on average for 4.7 years. In comparison, the subjects entered menopause at 49.14 years on average and the cough started at 52.6 years on average (Table 2).

Table 2

Ages and years since onset of menopause and cough symptoms $(n=66)$

\begin{tabular}{|lllll|}
\hline $\mathbf{n}=\mathbf{6 6}$ & $\begin{array}{l}\text { years since } \\
\text { menopause }\end{array}$ & $\begin{array}{l}\text { years onset of } \\
\text { cough }\end{array}$ & $\begin{array}{l}\text { age onset of } \\
\text { menopause (years) }\end{array}$ & $\begin{array}{l}\text { age onset of cough } \\
\text { (years) }\end{array}$ \\
\hline mean value & 8.05 & 4.74 & 49.14 & 52.60 \\
\hline $\begin{array}{l}\text { standard } \\
\text { deviation }\end{array}$ & 5.60 & 4.50 & 4.85 & 5.17 \\
\hline minimum & 1 & 0.15 & 36 & 36 \\
\hline maximum & 24 & 20 & 57 & 61 \\
\hline
\end{tabular}

\section{MRS results}

Tables 3 and 4 list the individual results of the MRS II comparing the 2 cohorts. In 2 of the 3 MRS domains (mental $(p=0.036)$, urogenital $(p<0.001)$, and somato-vegetative $(p<0.001)$ ), there is a highly significant difference between the subjects with versus without cough. A significant difference in mean MRS value among women in the cough group compared to women in the no-cough group was found in the following symptoms: heart discomfort, sleep problems, physical/mental exhaustion, sexual problems, vaginal dryness and joint/muscle complaints.(Table 3 ).

Figure 1shows the mean value comparison of the individual MRS items in both groups. 
Table 3

comparison of mean values and t-test of single MRS items ( $n=66$ with cough, $n=134$ without cough) MRS items

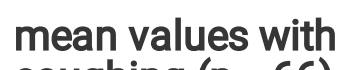

coughing $(n=66)$ mean values without

coughing $(n=134)$ difference $\mathrm{t}$-test

p-

0.192

1) hot flashes,

1.39

1.19

0.2

0.51

0.37

0.58

0.19

0.66

0.06

0.80

0.51

0.25

0.39

0.91

0.5

0.24

0.46

0.45

1.13

0.41

1.17

1.58

0.82

0.002 discomfort

Table 4

Mean values and t-test of total score and MRS domains ( $n=66$ with cough, $n=134$ without cough)

\begin{tabular}{|lllll|}
\hline MRS & $\begin{array}{l}\text { mean values with } \\
\text { cough } \\
(\mathbf{n = 6 6 )}\end{array}$ & $\begin{array}{l}\text { mean values without } \\
\text { cough } \\
(\mathbf{n = 1 3 4 )}\end{array}$ & difference & $\begin{array}{l}\text { t-test } \mathbf{p} \text { - } \\
\text { value }\end{array}$ \\
\hline MRS total score & 13,14 & 9,51 & 3,63 & $<0,001$ \\
\hline $\begin{array}{l}\text { MRS somato- } \\
\text { veg. } \\
\text { (items 1,2,3,11) }\end{array}$ & 5,77 & 4,22 & 1,55 & $<0,001$ \\
\hline $\begin{array}{l}\text { MRS urogenital } \\
\text { (items 8,9,10) }\end{array}$ & 3,59 & 2,42 & 1,17 & $<0,001$ \\
\hline $\begin{array}{l}\text { MRS mental } \\
\text { (items 4,5,6,7) }\end{array}$ & 3,77 & 2,87 & 0,9 & 0,036 \\
\hline
\end{tabular}

LCQ Results 
The LCQ score was 112.8 among the subjects with a chronic cough and 131.4 among the subjects without cough $(p<0.001)$. We compared the mean values of the subscale values for the LCQ domains (physically, socially, and psychologically). Comparing the subjects with cough versus no cough resulted in a score of 46.2 versus $54.4(p<0.005), 23.5$ versus $27.9(p<0.005)$ and 43.1 versus $49.0(p<0.005)$, respectively (Table 5).

Table 5

Mean values and t-test of total score and LCQ domains

\begin{tabular}{|c|c|c|c|c|c|}
\hline LCQ & $\begin{array}{l}\text { mean values with } \\
\text { coughing } \\
(n=66)\end{array}$ & $\begin{array}{l}\text { mean values without } \\
\text { coughing } \\
(n=134)\end{array}$ & $\max$. & diff. & $\begin{array}{l}\text { t-test } \\
\text { p- } \\
\text { value }\end{array}$ \\
\hline LCQ total score & 112,83 & 131,37 & 133 & 18,54 & $\begin{array}{l}<, 001\end{array}$ \\
\hline $\begin{array}{l}\text { LCQ physical } \\
\text { (items } \\
1,2,3,9,10,11,14,15)\end{array}$ & 46,21 & 54,40 & 56 & 8,19 & $\begin{array}{l}< \\
0,001\end{array}$ \\
\hline $\begin{array}{l}\text { LCQ mental } \\
\text { (items } \\
4,5,6,12,13,16,17 \text { ) }\end{array}$ & 43,09 & 49,00 & 49 & 5,19 & $\begin{array}{l}<, 001 \\
0,001\end{array}$ \\
\hline $\begin{array}{l}\text { LCQ social } \\
\text { (items } 7,8,18,19 \text { ) }\end{array}$ & 23,53 & 27,97 & 36 & 4,44 & $\begin{array}{l}< \\
0,001\end{array}$ \\
\hline
\end{tabular}

The results of the individual LCQ-items in comparison of the two groups are shown in Fig. 2 and Table 6 $(p<0.001)$.

Table 6 mean values and t-test of single LCQ items 


\begin{tabular}{|c|c|c|c|c|}
\hline$n=200$ & $\begin{array}{l}\text { mean values with } \\
\text { cough } \\
(n=66)\end{array}$ & $\begin{array}{l}\text { mean values without } \\
\text { cough } \\
(n=134)\end{array}$ & diff. & $\begin{array}{l}\text { t-test } p- \\
\text { value }\end{array}$ \\
\hline 1) chest / abdominal pain & 6,61 & 6,99 & 0,38 & $<0,001$ \\
\hline 2) sputum production & 5,68 & 6,95 & 1,27 & $<0,001$ \\
\hline 3) fatigue & 6,42 & 7,00 & 0,58 & $<0,001$ \\
\hline 4) cough control & 5,68 & 7,00 & 1,32 & $<0,001$ \\
\hline 5) anxiety & 5,85 & 7,00 & 1,15 & $<0,001$ \\
\hline 6) impingment of life & 6,45 & 7,00 & 0,55 & $<0,001$ \\
\hline 7) lack of quality of life & 5,70 & 7,00 & 1,30 & $<0,001$ \\
\hline 8) mood impairment & 6,45 & 7,00 & 0,55 & $<0,001$ \\
\hline 9) trigger paint, fumes & 5.74 & 6,71 & 0,97 & $<0,001$ \\
\hline 10) sleep problems & 5,85 & 6,98 & 1,13 & $<0,001$ \\
\hline 11) coughing fits & 5,29 & 6,89 & 1,60 & $<0,001$ \\
\hline 12) dispondance & 6,47 & 7,00 & 0,53 & $<0,001$ \\
\hline 13) irritability & 6,18 & 7,00 & 0,82 & $<0,001$ \\
\hline 14) hoarseness & 5,86 & 6,91 & 1,05 & $<0,001$ \\
\hline 15) lack of energy & 4,77 & 5,99 & 1,22 & $<0,001$ \\
\hline 16) worry about illness & 6,23 & 7,00 & 0,77 & $<0,001$ \\
\hline 17) fear of condemnation & 6,23 & 7,00 & 0,77 & $<0,001$ \\
\hline $\begin{array}{l}\text { 18) interruption of } \\
\text { conversation }\end{array}$ & 5,68 & 6,97 & 1,29 & $<0,001$ \\
\hline $\begin{array}{l}\text { 19) disruptive factor for } \\
\text { others }\end{array}$ & 5,70 & 7,00 & 1,30 & $<0,001$ \\
\hline
\end{tabular}

\section{Correlation MRS and LCQ}

A correlation analysis of the MRS scale versus the LCQ scale was applied to the whole cohort. Results are presented in Table 7. There is a negative correlation of -0.428 between the total LCQ and MRS scores. After controlling for age, BMI and years since menopause, the result remains significant (-0.429). Correlating the overall MRS score with the three LCQ domains results in a negative correlation from 0.336 to -0.481 . In particular, the LCQ domain for the physical symptoms of cough correlates negatively with the entire postmenopausal symptoms. As expected LCQ total score correlates very high with the 
mental, physical and social dimension of cough. A high correlation between the MRS total score and the three MRS-D domains could be shown.

Table 7

correlations of the results of MRS and LCQ $(n=200)$

\begin{tabular}{|c|c|c|c|c|c|c|c|c|}
\hline$n=200$ & $\begin{array}{l}\text { LCQ } \\
\text { total } \\
\text { score }\end{array}$ & $\begin{array}{l}\text { MRS } \\
\text { total } \\
\text { score }\end{array}$ & $\begin{array}{l}\text { LCQ } \\
\text { social }\end{array}$ & $\begin{array}{l}\text { LCQ } \\
\text { mental }\end{array}$ & $\begin{array}{l}\text { LCQ } \\
\text { physical }\end{array}$ & $\begin{array}{l}\text { MRS } \\
\text { somato- } \\
\text { vegetative }\end{array}$ & $\begin{array}{l}\text { MRS } \\
\text { uro- } \\
\text { genital }\end{array}$ & $\begin{array}{l}\text { MRS } \\
\text { mental }\end{array}$ \\
\hline $\begin{array}{l}\text { LCQ total } \\
\text { score }\end{array}$ & 1 & & & & & & & \\
\hline $\begin{array}{l}\text { MRS total } \\
\text { score }\end{array}$ & $-0,428$ & 1 & & & & & & \\
\hline LCQ social & 0,953 & $-0,336$ & 1 & & & & & \\
\hline LCQ mental & 0,959 & $-0,367$ & 0,928 & 1 & & & & \\
\hline LCQ physical & 0,955 & $-0,481$ & 0,848 & 0,846 & 1 & & & \\
\hline $\begin{array}{l}\text { MRS } \\
\text { somato- } \\
\text { vegetative }\end{array}$ & $-0,382$ & 0,841 & $-0,296$ & $-0,323$ & $-0,436$ & 1 & & \\
\hline $\begin{array}{l}\text { MRS } \\
\text { urogenital }\end{array}$ & $-0,365$ & 0,734 & $-0,294$ & $-0,322$ & $-0,399$ & 0,431 & 1 & \\
\hline MRS mental & $-0,299$ & 0,844 & $-0,233$ & $-0,254$ & $-0,339$ & 0,558 & 0,449 & 1 \\
\hline
\end{tabular}

\section{Logistic regression}

A logistic regression to predict cough based on the presence of postmenopausal symptoms was performed. At the level of the individual items, no significant predictive value for chronic cough could be recorded. However, on the basis of the MRS total score and the individual domains, highly significant results with regard to the total score $(p<0.001)$ and significant results with regard to the somatovegetative and urogenital domains $(p<0.05)$ remained (Table 8$)$. 
Table 8

Coefficient table of the logistic regression based on the MRS total score and the MRS domains $(n=200)$

\begin{tabular}{|lllll|}
\hline $\mathbf{n}=\mathbf{2 0 0}$ & $\mathbf{r c}$ & $\mathbf{p}$-value & odds ratio & $\mathbf{9 5 \%} \mathrm{Cl}$ \\
\hline MRS total score & 0,09 & $<0,001$ & 1,091 & $1,040-1,144$ \\
\hline $\begin{array}{l}\text { MRS somato-vegetative } \\
\text { (items 1,2,3,11) }\end{array}$ & 0,15 & 0,024 & 1,164 & $1,020-1,328$ \\
\hline $\begin{array}{l}\text { MRS urogenital } \\
\text { (items 8,9,10) }\end{array}$ & 0,18 & 0,025 & 1,195 & $1,023-1,396$ \\
\hline $\begin{array}{l}\text { MRS mental } \\
\text { (items 4,5,6,7) }\end{array}$ & 0,04 & 0,600 & 0,965 & $0,844-1,103$ \\
\hline Rc regression coeffiecient; Cl confidence interval & \\
\hline
\end{tabular}

\section{Discussion}

The main finding of this study is a strong association between chronic cough and climacteric symptoms in postmenopausal women. The women in this study were a generally healthy cohort who mostly visited the outpatient department for preventive or prophylactic exams, as well as for menopausal complaints. Of the 200 postmenopausal women, 33\% showed mild to severe symptoms of chronic cough for over 8 weeks. When comparing these women to the women with chronic cough both cohorts did not differ in baseline characteristics such as age, weight, number of diseases or years since onset of menopause (Table 1). In the affected women, the cough started at an average of 3.5 years after entering menopause.

Chronic cough was clearly associated with an increase of menopausal symptoms and especially in regard to the subscales of the MRS II that mirror urogenital and somato-vegetative symptoms (Table 3 , Fig. 1, Table 4). In addition, the results of the MRS and LCQ correlated with one another (Table 7). Furthermore, a significant prediction for chronic cough based on two somatic MRS domains and the total score could be shown (Table 8). These results contribute well to the biologically plausible theory that changes in the skin and mucous membranes can also show up in the respiratory tract, can change the sensitivity of the cough receptors and thus lead to increased cough sensitivity. The skin and mucous membranes represent an organ that can be influenced by hormonal changes. Decreasing estrogen level influence skin's glycosaminoglycan content and promote tendency to create wrinkles, dryness, atrophy and poor wound healing $[33,34]$. The collagen content of the skin is significantly reduced by $1-2 \%$ per year after menopause [36]. Some of these changes might also affect the respiratory system, a fact that was not yet the focus of either pulmonologists or gynecologists. Furthermore, lung function is strongly influenced by the female cycle and menopause [21, 27]. 
Chronic cough is a multifactorial symptom that can be the consequence of several pulmonary and extrapulmonary diseases including gastrooesophageal reflux, upper airway cough syndrome, obstructive sleep apnea, and medications such as ACE inhibitors [10,37-40). However, in a number of patients the genesis of chronic cough remains unclear, despite extensive diagnostics, then it is defined as chronic cough of unclear etiology or as chronic idiopathic cough (CIC). The clinical complaints of CIC, sometimes persisting for years, are a dry and excruciating cough, the urge to clear the throat and dysphagia $[1,2]$. According to recent literature, idiopathic cough occurs in up to $20-42 \%$ of cases of chronic cough and can be triggered by weak subclinical triggers such as gastric acid, thermal stimuli, or passive smoking [41]. In most cases, chronic idiopathic cough is difficult to treat as it does not respond to classic therapeutic options. Most patients treated in a cough clinic are not only female, but also postmenopausal $[1,16]$. Due to the reaction to subclinical triggers, the clinical picture of chronic idiopathic cough is causally associated with cough hypersensitivity syndrome, which defines a disturbance in the sensory nerve function. The concept of hypersensitivity is described as a valid and clinically useful concept and can be seen as a neuropathy of the cough reflex $[42,46]$. Accordingly, the cough receptors' increased sensitivity and the changed central cough modulations lead to hyperreactivity of the cough reflex $[33,34]$. In postmenopausal women, the chronic cough stimulus is also due to the cough receptors' increased sensitivity and/or a changed central cough modulation [12-16]. However, according to the definition, no $\mathrm{CIC}$ can be assigned to the patients in this study, as they did not go through the necessary diagnostics.

The highly significant correlation of postmenopausal symptoms, especially the somato-vegetative subgroup and vaginal dryness and coughing, underline these assumptions and emphasize the need to further expand the complexity of the climacteric syndrome. Chronic (idiopathic) cough might be, in part, due to the lack of steroids in postmenopausal women and could be diagnosed and treated differently in the future. Further studies are needed to clarify the connections, the underlying pathomechanisms, and the effects of hormonal replacement therapy on the bronchopulmonary symptoms.

A limitation of this study it that it is a simple interview and questionnaire-based study with no additional information on individual findings such as mucus parameters, $x$-rays etc. On the other hand, a strength of this study is that a reasonable and well-selected representative number of patients was involved. Also, the groups appeared to be well-balanced to baseline characteristics, the effects shown are statistically substantiated and the questionnaires that were used are validated and established tools to measure the aimed effects. At first glance a rate of $33 \%$ of rather healthy postmenopausal patients that report coughing might seem high and was a surprising finding. On the other hand, existing cough was mainly defined by the time aspect of 8 weeks and most women reported rather mild symptoms. The LCQ values are lower in patients with COPD and chronically productive cough [47].

Therefore postmenopausal women might not be aware of their symptoms or relate them to their postmenopausal changes.

In addition, there is disagreement about the exact prevalence of chronic cough $[48,49]$. 


\section{Conclusion}

In conclusion, the results of our study demonstrate a clinically relevant, statistically significant relationship between climacteric symptoms and postmenopausal cough, along with a significantly reduced quality of life in women with postmenopausal chronic cough. These associations should raise awareness, regarding this previously unknown climacteric syndrome and serve as a basis for further evaluation and should add another facet to the climacteric syndrome.

\section{Abbreviations}

$\mathrm{BMI}$ - body mass index

MRS -Menopause Rating Scale

LCQ- Leicester Cough Questionnaire

$\mathrm{CIC}$ - chronic idiopathic cough

COPD- chronic obstructive pulmonary disease

\section{Declarations}

Ethics approval and consent to participate

The study was conducted in accordance to the guidelines and with approval of the local ethics committee of the Philipps-University of Marburg. This confirms that all methods were carried out in accordance with the relevant guidelines and regulations. It is hereby confirmed that all test protocols have been confirmed by the named ethics committee. After detailed explanation of the purpose of the study, informed consent to participate in the study was obtained from all subjects. The declaration of consent was obtained in writing.

Consent for publication

Not applicable

Availability of data and material

The datasets used and/or analyzed during the current study are available from the corresponding author on reasonable request.

Competing interests

The authors declare that they have no competing interests

Funding 
none

Authors' contributions

VZ: project development, data collection and management, Data analysis, Manuscript writing/editing

TSO: project development, data collection and management, Data analysis, Manuscript writing/editing

WC: project development, Data analysis, Manuscript editing

$\mathrm{OH}:$ project development Manuscript editing

RK: project development Manuscript editing

UK: project development, Manuscript writing/editing

Acknowledgements

We would like to thank all subjects who agreed to take part in this study.

\section{References}

1. Kardos P, Berck H, Fuchs KH, et al. Guidelines of the German Respiratory Society for diagnosis and treatment of adults suffering from acute or chronic cough. Pneumologie. 2010;64:701-11.

2. Kardos P. Chronic idiopathic cough. Dtsch Med Wochenschr. 2017;142:197-200.

3. Koehler U, Hildebrandt O, Walliczek U, et al. Chronic cough: new diagnostic options? Dtsch Mediz Wochenschr. 2017;142:47-53.

4. Morice $A H$, Jakes $A D$, Faruqi $S$, et al. A worldwide survey of chronic cough: a manifestation of enhanced somatosensory response. Eur Respir J. 2014;44:1149-55.

5. Brignall K, Jayaraman B, Birring SS. Quality of life and psychosocial aspects of cough. Lung. 2008;186:55-8.

6. Dicpinigaitis PV, Tso R, Banauch G. Prevalence of depressive symptoms among patients with chronic cough. Chesti. 2006;130:1839-43.

7. Chan KKY, Ing AJ, Laks L, et al. Chronic cough in patients with sleep-disordered breathing. Eur Respir J. 2010;35:368-72.

8. Decalmer S, Stovold R, Houghton LA, et al. Chronic cough: relationship between microaspiration, gastroesophageal reflux, and cough frequency. Chest. 2012;142:958-64.

9. Dicpinigaitis PV. Angiotensin-converting enzyme inhibitor-induced cough: ACCP evidence-based clinical practice guidelines. Chest. 2006;129:169-73.

10. Emilsson Öl, Bengtsson A, Franklin KA, et al. Nocturnal gastrooesophageal reflux, asthma and symptoms of OSA: a longitudinal, general population study. Eur Respir J. 2013;1347-1354. 
11. Palombini BC, Villanova CAC, Araujo E, et al. A pathogenetic triad in chronic cough: asthma, postnasal drip syndrome, and gastrooesophageal reflux disease. Chest. 1999;116:279-84.

12. Dicpinigaitis PV, Rauf K. The influence of gender on cough reflex sensitivity. Chest. 1998;113:131921.

13. Fujimura M, Kasahara K, Kamio $Y$, et al. Female gender as a determinant of cough threshold to inhaled capsaicin. Eur Respir J. 1996;9:1624-6.

14. Kardos P. Chronic idiopathic cough. Dtsch Med Wochenschr. 2017;142:197-200.

15. Kelsall A, Decalmer, McGuiness K, et al. Sex differences and predictors of objective cough frequency in chronic cough. Thorax. 2009;64:393-8.

16. Plevkova J, Buday T, Kavalcikova-Bogdanova N,et al. Sex differences in cough reflex. Respir Physiol Neurobiol. 2017;245:122-9.

17. Lugo T, Tetrokalashvili M. Hot Flashes. [Updated 2021 Dec 28]. In: StatPearls [Internet]. Treasure Island (FL): StatPearls Publishing; 2022. Jan-.

18. .Mili N, Paschou SA, Armeni Aet al. Genitourinary syndrome of menopause: a systematic review on prevalence and treatment. Menopause. 2021;28(6):706-16.

19. Makwana N, Shah M, Chaudhary M. Vaginal pH as a Diagnostic Tool for Menopause: A Preliminary Analysis. J mid-life health. 2020;11(3):133-6. DOl:10.4103/jmh.JMH_1_20.

20. Khatoon A, Husain S, Husain S, Hussain S. An Overview of Menopausal Symptoms Using the Menopause Rating Scale in a Tertiary Care Center. J mid-life health. 2018;9(3):150-4.

21. Behan $M$, Zabka AG, Thomas $C F$, et al. Sex steroid hormones and the neural control of breathing. Respir Physiol Neurobiol. 2003;136(2-3):249-63.

22. Memoalia J, Anjum B, Singh Net al. Decline in Pulmonary Function Tests after Menopause. J Menopausal Med. 2018;24(1):34-40.

23. Hayatbakhsh MR, Najman JM, O'Callaghan MJet al. Association between smoking and respiratory function before and after menopause. Lung. 2011;189(1):65-71.

24. Soylu ÖG, Akbay E, Akkoca ANet al.(2015): Does menopause effect nasal mucociliary clearance time? In: European archives of oto-rhino-laryngology: official journal of the European Federation of Oto-Rhino-Laryngological Societies (EUFOS) : affiliated with the German Society for Oto-RhinoLaryngology - Head and Neck Surgery 272 (2), S. 363-366.

25. Toppozada $\mathrm{H}$. The human nasal mucosa in the menopause (a histochemical and electron microscopic study). J Laryngol Otol. 1988;102(4):314-8.

26. Beule AG. (2010): Physiology and pathophysiology of respiratory mucosa of the nose and the paranasal sinuses. In: GMS current topics in otorhinolaryngology, head and neck surgery 9, Doc07.

27. Nappi C, Di Spiezio S, Attilio G, et al. Comparison of intranasal and transdermal estradiol on nasal mucosa in postmenopausal women. Menopause. 2004;11(4):447-55.

28. Birring SS, Prudon B, Carr AJ, et al. Development of a symptomatic specific health status measure for patients with chronic cough: Leicester Cough Questionnaire (LCQ). Thorax. 2003;58:339-43. 
29. Hauser GA, Huber IC, Keller PJ, et al. Evaluation der klimakterischen Beschwerden (Menopause Rating Scale MRS). Zentralblatt für Gynäkologie. 1994;116:16-23.

30. Hauser GA, Potthoff P, Rosemeier PJ, et al.: Die Selbstbeurteilungs-Skala für klimakterische Beschwerden (Menopause Rating Scale II).

31. Potthoff P, Heinemann LA, Schneider HP, et al. Menopause-Rating-Skala (MRS II): Methodische Standardisierung in der deutschen Bevölkerung. Zentralblatt für Gynäkologie. 2000;122:280-6.

32. Birring SS, Matos S, Patel RB, et al. Cough frequency, cough sensitivity and health status in patients with chronic cough. Respir Med. 2006;100:1105-9.

33. Faruqi S, Murdoch RD, Allum F, et al. On the definition of chronic cough and current treatment pathways: an international qualitative study. Cough. 2014;10:5. doi:10.1186/1745-9974-10-5.

34. Hall G, Phillips TJ. Estrogen and skin: the effects of estrogen, menopause, and hormone replacement therapy on the skin. J Am Acad of Dermatol. 2005;53:555-68.

35. Shah MG, Maibach HI. Estrogen and skin: an overview. Amer J Clin Dermatol. 2001;2:143-50.

36. Brincat M, Kabalan S, Studd JW, et al. A study of the decrease of skin collagen content, skin thickness, and bone mass in the postmenopausal woman. Obstet and Gynecol. 1987;70:840-5.

37. Chan KKY, Ing AJ, Laks L, et al. Chronic cough in patients with sleep-disordered breathing. Eur Respir J. 2010;35:368-72.

38. Decalmer S, Stovold R, Houghton LA, et al. Chronic cough: relationship between microaspiration, gastroesophageal reflux, and cough frequency. Chest. 2012;142:958-64.

39. Dicpinigaitis PV. Angiotensin-cconverting Enzyme Inhibitor-Induced Cough - ACCP Evidence-Based Clinical Practice Guidelines. Chest. 2006;129:169-73.

40. Palombini BC, Villanova CAC, Araujo E, et al. A pathogenetic triad in chronic cough - Asthma, postnasal drip syndrome, and gastrooesophageal reflux disease. Chest. 1999;116:279-84.

41. Chung KF. Approach to chronic cough: the neuropathic basis for cough hypersensitivity syndrome. J Thorac Dis. 2014;6:699-707.

42. Birring SS, Matos S, Patel RB, et al. Cough frequency, cough sensitivity and health status in patients with chronic cough. Respiratory Med. 2006;100:1105-9.

43. Chung KF. Chronic cough hypersensitivity syndrome: a more precise label for chronic cough. Pulm Pharmacol Ther. 2011;24:267-71.

44. Chung KF, Mc Garvey L, Mazzone SB. Chronic cough as a neuropathic disorder. Lancet Respir Med. 2013;1:414-22.

45. Chung KF. Approach to chronic cough: the neuropathic basis for cough hypersensitivity syndrome. J Thorac Dis. 2014;6:699-707.

46. Morice AH, Millqvist E, Belvisi MG, et al. Expert opinion on the cough hypersensitivity syndrome in respiratory medicine. Eur Respir J. 2014;44:1132-48.

47. Berkhof FF, Boom LN, Hertog NE, et al. (2012): The validity and precision of the Leicester Cough Questionnaire in COPD patients with chronic cough. In: Health and quality of life outcomes 10, S. 4. 
DOI: 10.1186/1477-7525-10-4.

48. Morice AH, Jakes AD, Faruqi S, et al. A worldwide survey of chronic cough. A manifestation of enhanced somatosensory response. Eur Respir J. 2014a;44(5):1149-55.

49. Song W-J, Chang Y-S, Faruqi S, et al. The global epidemiology of chronic cough in adults: a systematic review and meta-analysis. Eur Respir J. 2015;45(5):1479-81.

\section{Figures}

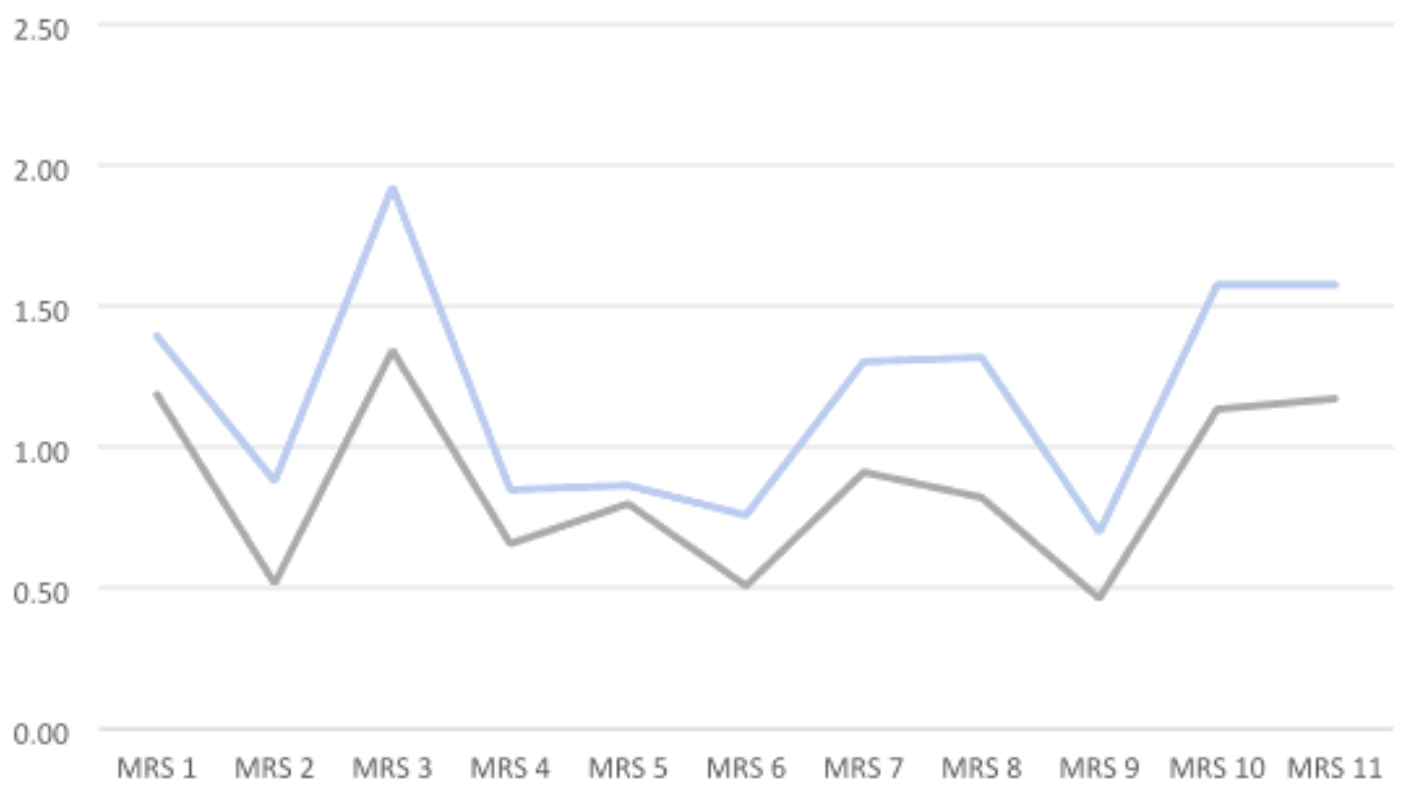

Figure 1

comparison of mean values of single MRS items ( $n=66$ with cough (blue), $n=134$ without cough (gray)) (graphic program: MS Office) 


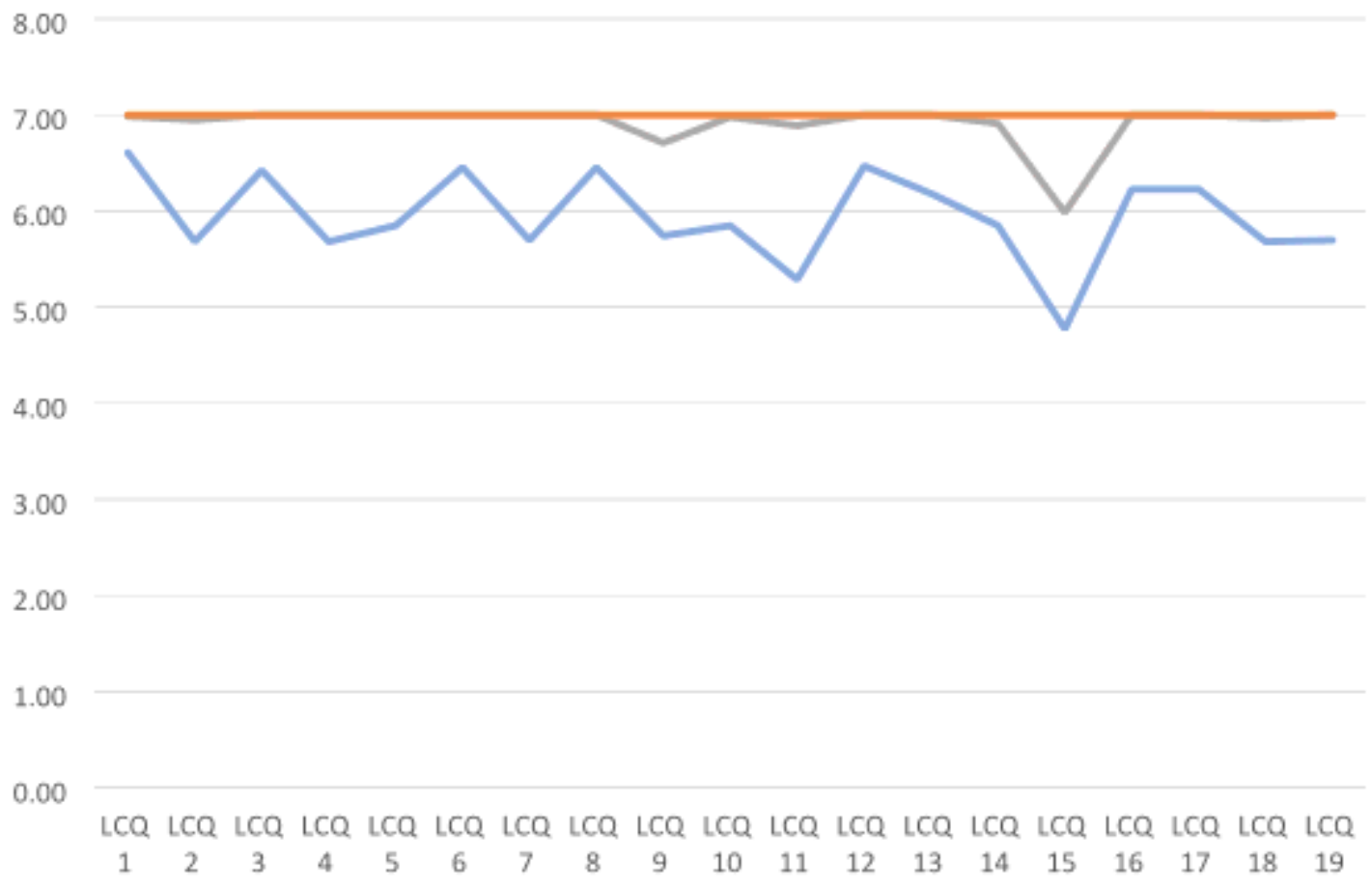

Figure 2

comparison of mean values of single LCQ items

( $\mathrm{n}=66$ with cough (blue), $\mathrm{n}=134$ without cough (gray), possible points (orange))

(graphic program: MS Office) 